\title{
Hydrogeochemical Characteristics and Water-Rock Interactions of Coalbed-Produced Water Derived from the Dafosi Biogenic Gas Field in the Southern Margin of Ordos Basin, China
}

\author{
Yuan Bao $\mathbb{D}^{1,2}$ Chao An, ${ }^{1}$ Chaoyong Wang $\mathbb{D}^{2}{ }^{2}$ Chen Guo, ${ }^{1}$ and Wenbo Wang ${ }^{1}$ \\ ${ }^{1}$ Geological Research Institute for Coal Green Mining, College of Geology and Environment, Xi'an University of Science \\ and Technology, Xi'an 710054, China \\ ${ }^{2}$ Key Laboratory of CBM Resource and Reservoir Formation Process, Ministry of Education, School of Resources and Geosciences, \\ China University of Mining and Technology, Xuzhou 221008, China
}

Correspondence should be addressed to Yuan Bao; baoyuan8384@163.com and Chaoyong Wang; wangcy@cumt.edu.cn

Received 12 April 2021; Accepted 21 May 2021; Published 8 June 2021

Academic Editor: Yanjun Meng

Copyright $\odot 2021$ Yuan Bao et al. This is an open access article distributed under the Creative Commons Attribution License, which permits unrestricted use, distribution, and reproduction in any medium, provided the original work is properly cited.

The hydrogeochemical characteristics of coalbed-produced water can provide insights into the sources of ions and water, the groundwater environments, hydrodynamic conditions, and water-rock interactions of depositional basins. To study the waterrock reaction process and reveal whether there is a microbial activity in the groundwater, a case of the Dafosi biogenic gas field was chosen by testing the ionic concentrations and hydrogen and oxygen isotopic compositions of coalbed-produced water and employing R-type cluster and principal component analyses. The results showed that $\mathrm{Na}^{+}, \mathrm{Cl}^{-}$, and $\mathrm{HCO}_{3}^{-}$are the principal ions in the coalbed-produced water, while the water type is mainly a $\mathrm{Na}-\mathrm{Cl}$. Due to the hydrolysis of $\mathrm{HCO}_{3}{ }^{-}$, the $\mathrm{pH}^{-}$in this region was controlled primarily by $\mathrm{HCO}_{3}{ }^{-}$. As the main cation in water, $\mathrm{Na}^{+}$contributed substantially to the total dissolved solids. $\mathrm{Na}^{+}$is also related to the exchange between rock-bound $\mathrm{Na}^{+}$and $\mathrm{Ca}^{2+}$ and $\mathrm{Mg}^{2+}$ in water or surrounding rocks. The coalbed-produced water's oxygen isotopes displayed a characteristic ${ }^{18} \mathrm{O}$ drift and enrichment, indicating that the ${ }^{16} \mathrm{O}$ isotope in the water was preferentially exchanged with the coal organic matter. Early evaporation is also contributed to the enrichment of TDS (total dissolved solids) and ${ }^{18} \mathrm{O}$ in the water. The central part of the study area, including the Qijia anticline, was affected by the Yanshanian uplift and denudation and subsequently developed a water-conducting fissure zone and was recharged atmospheric precipitation; these conditions were conducive to the formation of secondary biogenic gas.

\section{Introduction}

Coalbed methane (CBM), as a cleaner unconventional natural gas resource [1-3], has been widely prioritized development in major coal-producing countries (e.g., China, the United States, Canada, and Australia) [4-6]. The United States was the first to begin commercially developing CBM; China, Canada, and Australia are also entering the initial industrial CBM development stages [7]. In the mining of CBM, it is necessary to desorb the gas from the coal pores via drainage and reductions in pressure, which results in the discharge of coalbed-produced water. Important in this is that coalbed-produced water contains abundant geological information, which can positively impact CBM development.
Understanding the storage, migration, and development of CBM by identifying trends across strata and analyzing the water sources is of great value. Thus, in recent years, the geochemical characteristics of water produced from coalbed have attracted extensive attention worldwide [8-11].

Since Craig [12] first proposed the linear relationship between the hydrogen and oxygen isotopes in global precipitation $\left(\delta \mathrm{D}=8 \delta^{18} \mathrm{O}+10\right)$ as the global meteoric water line (GMWL), hydrogen and oxygen isotopic compositions have been widely used in hydrogeochemical research [13], primarily to determine the sources of water and the types of and mechanisms underlying water-rock interactions [14, 15]. The main types of water-rock interactions include ion exchange, calcite and dolomite precipitation, and the 
dissolution of silicates, gypsum, $\mathrm{CO}_{2}$, and evaporites [16-18]. Guo et al. [8] found that coalbed-produced waters in the Bide-Santang basin of western Guizhou exhibit a $D$ drift indicative of hydrogen content in the coalbed that is higher than that of oxygen and established a template for identifying water sources. Wu et al. [19] analyzed the hydrogen and oxygen isotopes of the water produced by CBM wells. They showed that it was mainly derived from atmospheric precipitation (i.e., meteoric water) and was subject to water-rock interactions and evaporation.

Various statistical methods (e.g., cluster analysis [20], canonical analysis [21], discriminant analysis [22], and principal component analysis $[9,23])$ have been adopted to study the relationships among groundwater ion concentrations, total dissolved solids (TDS), and $\mathrm{pH}$. Chemical changes that control coalbed-produced water have also been widely used for inference in different basins [24-26]. For example, Zhang et al. [9] studied the relationship between ions and suggested that the $\mathrm{Na}^{+}$and $\mathrm{HCO}_{3}{ }^{-}$concentrations in the Qinshui basin might be related to ion exchange and silicate weathering. $\mathrm{Li}$ et al. [21] analyzed the relationship between anions and cations in the Guohua phosphate mine of Guizhou province using cluster analysis. They asserted that natural effects, such as carbonate dissolution and rock weathering, were the main mechanisms affecting the mine's water chemistry. Redwan et al. [26] also studied the influence of the chemical characteristics of the water and water-rock interactions on the chemical elements of coal-bearing rocks and combined statistical methods to identify and evaluate water-rock reaction process. Thus, it has been demonstrated that analyses of the relationships between different ions in water can reveal the types of water-rock interactions occurring in a basin and the ion exchange processes. It is essential for exploring the primary ion sources of groundwater and CBM storage and migration.

The Dafosi gas field is located in the Binchang mining area of the Huanglong coal field along the Ordos basin's southern margin. The development potential of CBM resources is enormous, and its gas origin is biogenic gas [27]. Much research has been conducted on the occurrence and exploitation of CBM in this area. For example, favorable areas of CBM prospecting were identified by analyzing the thickness of coalbeds, hydrogeological conditions, CBM content, apex, and floor characteristics [28]. $\mathrm{Ma}$ et al. [2] stated that $\mathrm{CO}_{2}$-enhanced coalbed methane technologies are feasible and improve the recovery of CBM, while Lin et al. [29] studied the pores of Dafosi coal samples and established a gas drainage model to enhance the efficiency of CBM drainage. Bao et al. [27] analyzed the genetic types and distributions of gas in this area based on gas and stable isotope data, recognizing that the gas is mainly biogenic CBM. However, there are few studies focused on the water-rock interaction mechanism of the study area.

The ionic characteristics of coalbed-produced water and the water sources have an important influence on predicting areas enriched in CBM. Therefore, in this study, we collected nine water samples from different CBM drainage wells in the Binchang mining area of the Dafosi biogenic gas field and tested their main ionic and hydrogen and oxygen isotope compositions to analyze the compositional characteristics of ions, water type, and water source. The correlations among the main influencing factors of various hydrochemical parameters were examined through Pearson correlation analysis, cluster analysis, and principal component analysis. The ion source and groundwater environment of coalbed groundwater were also explored. These analyses enabled us to determine the mechanisms underlying the water-rock reaction process and reveal whether there is a microbial activity in the groundwater if the water comes from meteoric precipitation.

\section{Geological Setting}

The stratigraphic sequence in the study area is as follows: Upper Triassic Hujiacun Formation $\left(\mathrm{T}_{3} \mathrm{~h}\right)$, Lower Jurassic Fuxian Fm. $\left(\mathrm{J}_{1} \mathrm{f}\right)$, Middle Jurassic Yan'an Fm. $\left(\mathrm{J}_{2} \mathrm{y}\right)$, Zhiluo Fm. $\left(\mathrm{J}_{2} \mathrm{z}\right)$, Anding Fm. $\left(\mathrm{J}_{2} \mathrm{a}\right)$, Lower Cretaceous Yijun Fm. $\left(K_{1} y\right)$, Luohe Fm. $\left(K_{1} 1\right)$, Huachi Fm. $\left(K_{1} h\right)$, Neogene $(N)$, and Quaternary $(\mathrm{Q})$. The principal aquifer of the $\mathrm{K}_{1} \mathrm{l}$ is recharged by Quaternary phreatic water and surface water infiltration. Although the mudstone layer of the $\mathrm{K}_{1} \mathrm{~h}$ causes vertical recharge to be very weak, the $K_{1} h$ is missing in some areas, which provides the conditions necessary for the infiltration of water into the Luohe Fm. The site is rich in coal resources, the surface is covered by loess spanning a large area, and the strata are relatively flat. The deep Jurassic has a monoclinic structure with an $\mathrm{N} 60^{\circ}-70^{\circ}$ E strick and an NW-NNW tendency inherited from the Triassic basement.

The Ordos basin, in which the study area is located, is vast and complex. It may be divided into five water-bearing systems according to their hydrogeological structures and water-bearing media types [30]. These systems are the Cambrian-Ordovician, Cretaceous, Carboniferous-Jurassic, Cainozoic, and bedrock water systems (Figure 1(a)). The Dafosi gas field is located in the southern Binchang mining area of the Ordos basin (Figure 1(b)) and belongs to a Cretaceous clastic fissure-pore aquifer system.

The only coal-bearing strata in the Dafosi biogenic gas field is the Jurassic Yan'an Fm. The thickness of the strata ranges $\sim 40.05-168.57 \mathrm{~m}$ (average: $75.57 \mathrm{~m}$ ). There are unstable, thickly bedded sandstones at the bottom, limestone intercalated thick coalbeds in the lower layers, and medium-fine-grained sandstones in the middle. Sandstones and mudstones are interbedded with thin coalbeds, and the upper sandstones and mudstones interbedded with coal contain many plant fossils. The main coalbeds are nos. 4 and $4^{\text {upper }}$ coals, with the $4^{\text {upper }}$ coal being a bifurcated coalbed of the no. 4 coal, of which the average coal thickness is $17 \mathrm{~m}$, meaning that it is the most mineable. The average thickness of the no. 4 coal is $11.6 \mathrm{~m}$, and it is a mineable coalbed throughout the area. The Dafosi gas field is a specific biogenic gas mining area based on the gas component and its stable isotopes analysis [27].

CBM resources are rich in the Dafosi biogenic gas field. The coalbed permeability is $0.11-6.84 \mathrm{mD}$, and the coal structure is primary-cataclastic. Figure 1(c) shows the favorable area for CBM exploration and development. The fold 


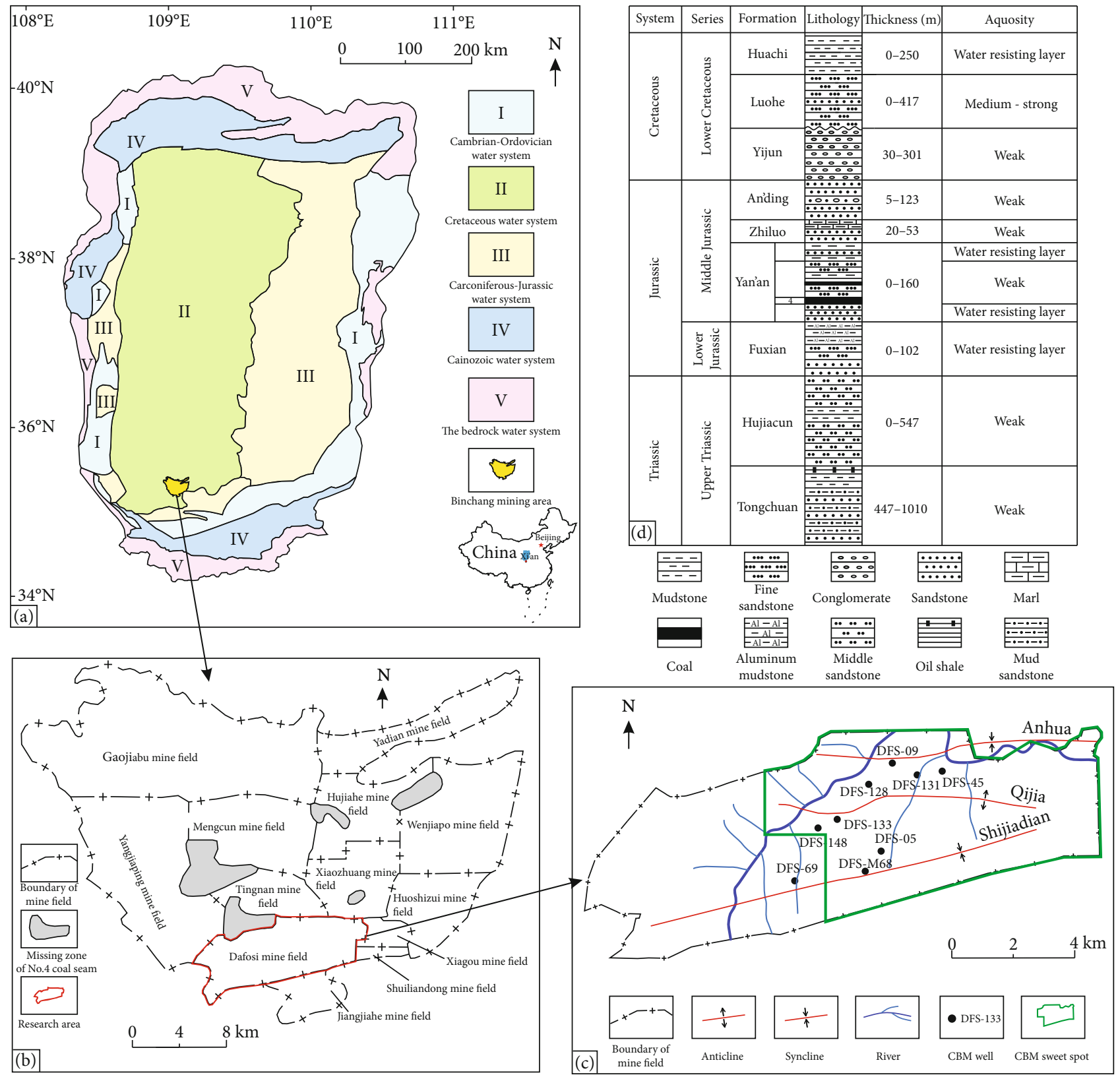

FIGURE 1: Regional structure, groundwater systems, and distribution of sampling locations: (a) groundwater systems; (b) distribution of mines in the Binchang mining area; (c) structure of the surface water system and sampling locations in the Dafosi biogenic gas field; (d) comprehensive stratigraphic column of the mining area.

structure developed in the Dafosi biogenic gas field is relatively broad and generally displays an undulating monoclinic system that includes the two synclines and one anticline (Figure 1(c)). The stratigraphic dip is relatively gentle, there are no igneous rocks, and the overall structure is simple. The Lower Jurassic Yan'an Fm is the primary coal-bearing unit in the study area (Figure 1(d)). The strata underlying this formation are the Lower Jurassic Fuxian Fm's mudstones, while the overlying strata include a fractured aquifer in the Middle Jurassic Zhiluo Fm. The study area's stratum integrity is good, and the roof and floor of the coalbed are mainly composed of mudstone and sandstone waterproof layers. There is no direct hydraulic connection between each layer. Therefore, the hydrogeological conditions in the mine area are of simple to moderate complexity.

\section{Materials and Methods}

The CBM wells in the study area have been producing gas continuously for more than 48 months [31]. Therefore, the collected coalbed-produced water can be regarded as the original formation of water. To characterize the water chemistry's distribution characteristics throughout the area, we designed three sampling lines along the fold direction. As the east side of the study area is a future CBM exploitation planning area, and the west side is an underground coal 
TABLE 1: Geochemical parameters and water types of coalbed-produced water.

\begin{tabular}{|c|c|c|c|c|c|c|c|c|c|}
\hline Parameters & DFS-05 & DFS-09 & DFS-45 & DFS-69 & $\begin{array}{c}\text { Sample ID } \\
\text { DFS-128 }\end{array}$ & DFS-131 & DFS-133 & DFS-148 & DFS-M68 \\
\hline $\mathrm{pH}$ & 8.2 & 7.9 & 8.1 & 9.0 & 7.7 & 8.0 & 8.3 & 8.3 & 7.2 \\
\hline TDS & 9828.0 & 14199.0 & 12545.7 & 14886.1 & 13819.2 & 13318.7 & 15076.0 & 16505.6 & 7601.9 \\
\hline $\mathrm{Na}^{+}$ & 3824.2 & 5395.5 & 4826.4 & 6052.0 & 5275.4 & 5045.2 & 5933 & 6367.6 & 2968.0 \\
\hline $\mathrm{K}^{+}$ & 13.0 & 18.8 & 18.4 & 8.1 & 19.3 & 59.1 & 14.5 & 30.8 & 9.4 \\
\hline $\mathrm{Mg}^{2+}$ & 15.0 & 59.5 & 40.2 & 5.2 & 50.1 & 47.9 & 8.7 & 10.8 & 11.5 \\
\hline $\mathrm{Ca}^{2+}$ & 52.0 & 109.8 & 60.5 & 7.7 & 81.3 & 79.9 & 7.6 & 12.8 & 30.3 \\
\hline $\mathrm{NH}_{4}^{+}$ & 11.3 & 16.9 & 23.2 & 0.0 & 21.8 & 15.4 & 9.2 & 0.0 & 9.7 \\
\hline $\mathrm{Cl}^{-}$ & 5457.7 & 8441.8 & 7238 & 6229.8 & 8118.7 & 7840.3 & 6462.1 & 6347.4 & 4096.6 \\
\hline $\mathrm{SO}_{4}{ }^{2-}$ & 4.3 & 2.2 & 22.6 & 126.9 & 3.3 & 7.5 & 1142.4 & 2385.7 & 1.2 \\
\hline $\mathrm{HCO}_{3}^{-}$ & 885.6 & 285.5 & 613.7 & 4092.2 & 477.0 & 427.1 & 2747.0 & 2426.1 & 936.5 \\
\hline $\mathrm{CO}_{3}^{2-}$ & 0.0 & 0.0 & 0.0 & 371.0 & 0.0 & 0.0 & 114.9 & 123.0 & 0.0 \\
\hline Water type & $\mathrm{Na}-\mathrm{Cl}$ & $\mathrm{Na}-\mathrm{Cl}$ & $\mathrm{Na}-\mathrm{Cl}$ & $\mathrm{Na}-\mathrm{Cl}-\mathrm{HCO}_{3}$ & $\mathrm{Na}-\mathrm{Cl}$ & $\mathrm{Na}-\mathrm{Cl}$ & $\mathrm{Na}-\mathrm{Cl}$ & $\mathrm{Na}-\mathrm{Cl}$ & $\mathrm{Na}-\mathrm{Cl}$ \\
\hline
\end{tabular}

Note: the unit of ions and TDS are $\mathrm{mg} / \mathrm{L}$.

mining area without CBM wells, our coalbed-produced water samples were mainly concentrated in the central study area. After sampling, the $10 \mathrm{~L}$ buckets were sealed and sent to the laboratory for testing immediately. The sampling locations are shown in Figure 1(c).

Ions of $\mathrm{K}^{+}, \mathrm{Na}^{+}, \mathrm{Mg}^{2+}, \mathrm{Ca}^{2+}, \mathrm{Cl}^{-}$, and $\mathrm{SO}_{4}{ }^{2-}$ in coalbedproduced water were detected by dual system ion chromatography (ICS-2000, Thermo Fisher Scientific, USA); $\mathrm{Fe}^{2+}$ was detected according to the coal industry-standard (MT/T) by colorimetry; $\mathrm{HCO}_{3}{ }^{-}, \mathrm{CO}_{3}{ }^{2-}$, and $\mathrm{pH}$ values were detected by corresponding titration and electrode methods according to the same standard. The $\mathrm{pH}$ was measured using a PP-50p11 meter (Sartorius, Germany), and a DDSJ-308A conductivity meter (Yantain Stark Instrument, Co., Ltd., China) was employed to measure TDS. The water's hydrogen and oxygen isotopic compositions were tested by LGR 912-0032 liquid water isotope analyzer (Los Gatos Research, USA) at the key laboratory of water disaster prevention and control in Shaanxi province. The Vienna standard mean ocean water (V-SMOW) standard was employed for stable isotopic analysis, and the analytical accuracies were $\delta \mathrm{D}< \pm 0.5 \%$ and $\delta^{18} \mathrm{O}< \pm 0.2 \%$, respectively.

\section{Results and Discussion}

4.1. Ionic Compositions and $p H$ Values. Table 1 shows the main ion contents, $\mathrm{pH}$ values, TDS, and other basic geochemical data of the coalbed-produced water in the Dafosi biogenic gas field. The study area's $\mathrm{pH}$ ranges from 7.7 to 9.0 (average: 8.1 ), showing weak alkalinity. The concentration of TDS ranges from 7601.9 to $16505.6 \mathrm{mg} / \mathrm{L}$. The mining area is relatively enriched in $\mathrm{Na}^{+}, \mathrm{Cl}^{-}$, and $\mathrm{HCO}_{3}{ }^{-}$and poor in $\mathrm{Ca}^{2+}, \mathrm{Mg}^{2+}$, and $\mathrm{SO}_{4}{ }^{2-}$. The trends are similar to those observed in previous studies, such as the Zhijin block and Dingji coal mine $[32,33]$. The order of cation content is as follows: $\mathrm{Na}^{+}>\mathrm{Ca}^{2+}>\mathrm{Mg}^{2+}>\mathrm{K}^{+}>\mathrm{NH}_{4}{ }^{+}$. Sodium contents range from 2968 to $6367.6 \mathrm{mg} / \mathrm{L}$ and account for $>96 \%$ of all cations. The order of anion content is $\mathrm{Cl}^{-}>\mathrm{HCO}_{3}{ }^{-}>-$
$\mathrm{SO}_{4}{ }^{2-}>\mathrm{NO}_{3}{ }^{-}$, in which the $\mathrm{Cl}^{-}$content ranges from 4096.6 to $8441.8 \mathrm{mg} / \mathrm{L}$ and accounts for $60-97 \%$ of all anions.

The lowest $\mathrm{HCO}_{3}{ }^{-}$concentration was $285.5 \mathrm{mg} / \mathrm{L}$, and the highest was $4092.2 \mathrm{mg} / \mathrm{L}$, accounting for $3-40 \%$ of all anions. The difference in the $\mathrm{HCO}_{3}{ }^{-}$concentrations reflected the different well locations and may be related to the dissolution of $\mathrm{CO}_{2}$ in CBM. The water type of the coalbed-produced was mainly $\mathrm{Na}-\mathrm{Cl}$ in the study area, containing a small $\mathrm{Na}-\mathrm{Cl}-\mathrm{HCO}_{3}$-type (Table 1 and Figure 2). The TDS of the research area was high, with the lowest being $7601.9 \mathrm{mg} / \mathrm{L}$ and the highest being $16505.6 \mathrm{mg} / \mathrm{L}$. Because the average concentration of $\mathrm{Na}^{+}$ in the coalbed-produced water was $5076 \mathrm{mg} / \mathrm{L}$, while that of $\mathrm{Ca}^{2+}$ was only $49 \mathrm{mg} / \mathrm{L}$, the ratio of $\mathrm{Na}^{+} /\left(\mathrm{Na}^{+}+\mathrm{Ca}^{2+}\right)$ ranged between 0.98 and 1 , with an average of 0.99 . Although no extremes in $\mathrm{Na}^{+} /\left(\mathrm{Na}^{+}+\mathrm{Ca}^{2+}\right)$ were observed, the ratio of $\mathrm{Cl}^{-} /\left(\mathrm{Cl}^{-}+\mathrm{HCO}_{3}{ }^{-}\right)$exceeded 0.6 , with an average of 0.83 . By projecting Dafosi coalbed-produced water data into a Gibbs diagram (Figure 3), it was found that the $\mathrm{Na}^{+} /\left(\mathrm{Na}^{+}+\mathrm{Ca}^{2+}\right)$ and $\mathrm{Cl}^{-} /\left(\mathrm{Cl}^{-}+\mathrm{HCO}_{3}{ }^{-}\right)$values all plotted in the upper right corner, indicating that the ions in this water were affected by evaporation.

4.2. Isotopic Compositions of Hydrogen and Oxygen and Identification of Water Source. When a water sample receives atmospheric precipitation, it will plot on the China meteoric water line (CMWL) [35]. In contrast, water samples subject to evaporation or water-rock interaction will generally deviate plot below the line [36]. Table 2 shows that the hydrogen and oxygen isotopic compositions of water produced by CBM wells were relatively close, with $\delta \mathrm{D}$ values ranging from $-85.8 \%$ o to $-79.5 \%$ o (average: $-82.3 \%$ ) and $\delta^{18} \mathrm{O}$ values ranging from $-12.2 \%$ to $-9.3 \%$ (average: $-11 \%$ ). Projection of these composition data in Figure 4 revealed that most well data in the study area were distributed below the CMWL and displayed an ${ }^{18} \mathrm{O}$ drift, reflecting a strong evaporation existence in this region (line slope is 1.87). Only the data for well DFS-133 plotted along the CMWL, while those of 


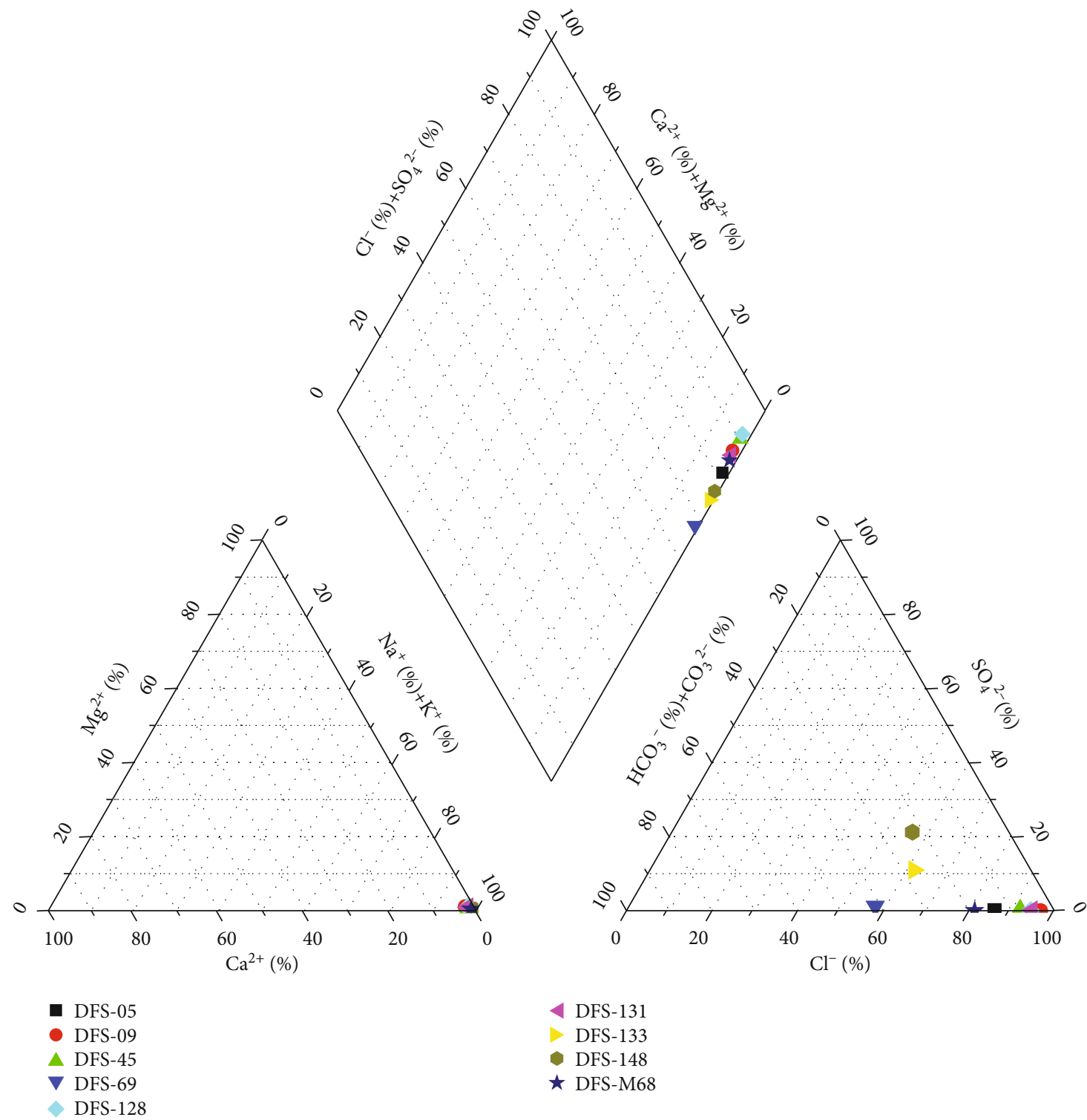

FIgure 2: Piper diagram of coalbed-produced water in the Dafosi biogenic gas field indicating the water type.

three wells, DFS-148, DFS-131, and DFS-M68, plotted close to this line. The information for the remaining five wells deviated markedly from the CMWL.

4.3. Multivariate Statistical Analyses of Different Geochemical Indicators. Analyzing the correlations between different ion contents is a simple and effective method by which the geochemical characteristics of coalbed-produced waters may be studied [37, 38]. We analyzed the correlations between major ions in coalbed-produced water using Pearson's correlation analyses performed in SPSS v. 21 (IBM Corp., USA). As shown in Table 3, the correlation between TDS and $\mathrm{Na}^{+}$ reached $R^{2}=0.994$ at a significance level of $p=0.01$, which indicates that $\mathrm{Na}^{+}$in this area contributed greatly to TDS. The $\mathrm{pH}$ value was significantly correlated with $\mathrm{CO}_{3}{ }^{2-}, \mathrm{Na}^{+}$, $\mathrm{HCO}_{3}^{-}$, and $\mathrm{HCO}_{3}{ }_{3}^{-}$, among which $\mathrm{HCO}_{3}{ }^{-}, \mathrm{CO}_{3}{ }^{2-}$, and $\mathrm{pH}$ displayed the most apparent positive relationships, reaching $R^{2}=0.758$ and $R^{2}=0.808$, respectively.
Factor analysis is a process of reducing the dimensionality of data. Several original variables with specific correlations are collated into a new variable, and the newly constructed variable represents the overall difference in the data caused by such variables. This approach can reduce the number of variables needed to explain the variance in the data while maintaining much of the original integrity of the data [39] and enabling us to analyze the relationship between ions in coalbeds rapidly. As the two ends of the rotated factor loading matrix are concentrated, which can better explain the main factors, we used the rotated factor loads and extracted the four main elements, principal components 1-4 (i.e., PC1, PC2, PC3, and PC4). According to the component matrix (Table 4) and total variance (Table 5) obtained via factor rotation of the maximum variance in SPSS, the variance described by the four factors was obtained. The most important four factors accounted for $32.61 \%, 32.36 \%, 21.74 \%$, and $10.76 \%$ of 


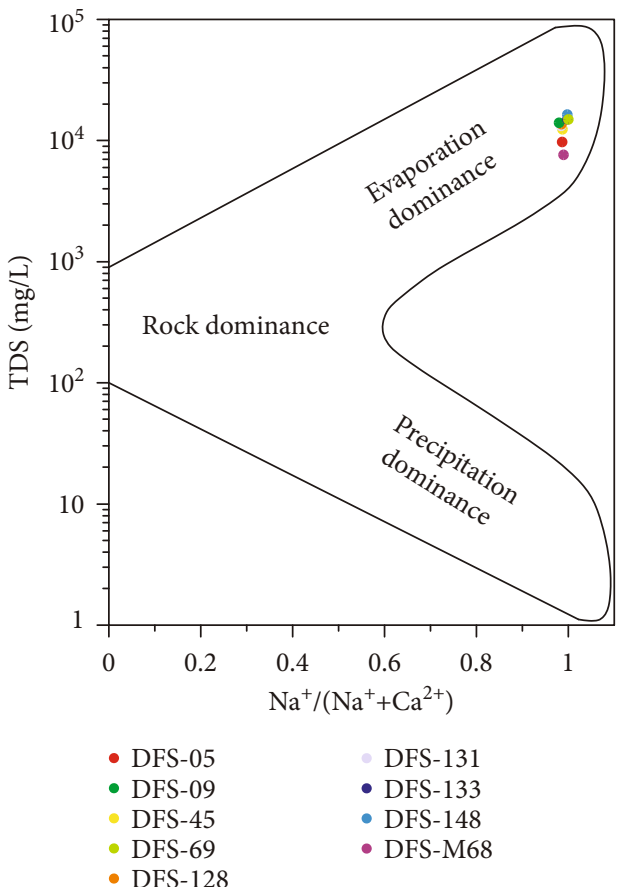

(a)

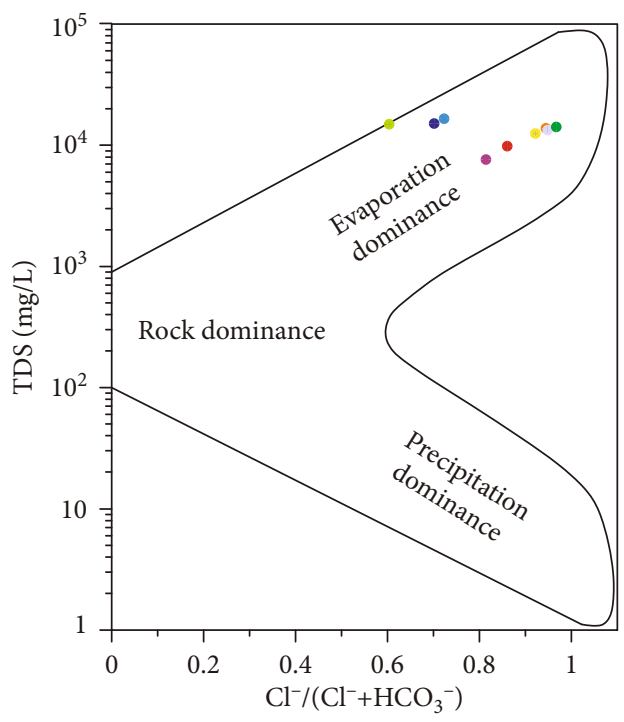

(b)

FIGURE 3: Gibbs distribution model of coalbed-produced water indicating the ionic reactions (modified from the literature [34]).

TABle 2: Hydrogen and oxygen isotopic compositions of coalbed-produced water in the Dofosi biogenic gas field.

\begin{tabular}{lccccccccc}
\hline & & \multicolumn{3}{c}{ Sample ID } & DFS-131 & DFS-133 & DFS-148 & DFS-M68 \\
\hline$\delta \mathrm{D}(\%)$ & -84.2 & -80.0 & -81.5 & -83.5 & -81.4 & -79.5 & -84.5 & -85.8 & -81.7 \\
$\delta^{18} \mathrm{O}(\%)$ & -12.2 & -9.3 & -10.5 & -11.0 & -10.2 & -10.8 & -11.8 & -11.7 & -11.2 \\
\hline
\end{tabular}

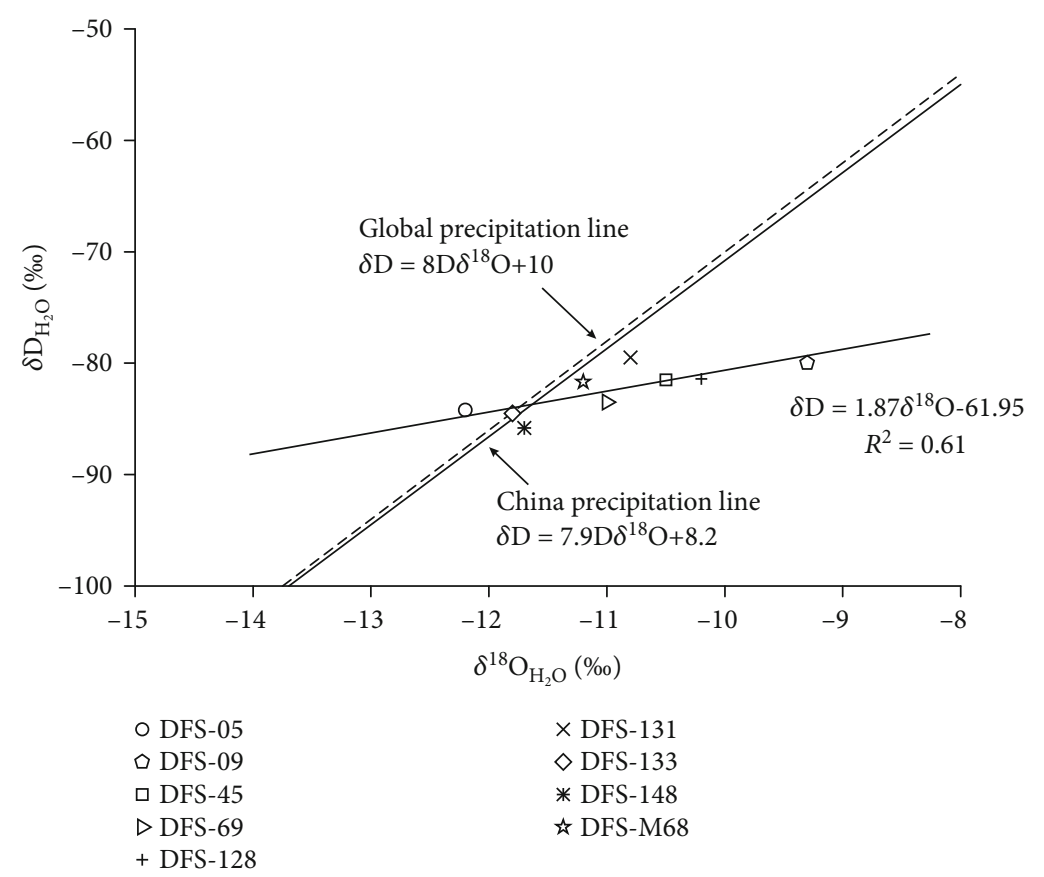

FIGURE 4: Relationship between $\delta \mathrm{D}\left(\mathrm{H}_{2} \mathrm{O}\right)$ and $\delta^{18} \mathrm{O}\left(\mathrm{H}_{2} \mathrm{O}\right)$ in coalbed-produced water of the Dafosi biogenic gas field. 
TABLE 3: Pearson's correlation matrix between hydrogeochemical parameters of water samples.

\begin{tabular}{|c|c|c|c|c|c|c|c|c|c|c|}
\hline & $\mathrm{pH}$ & TDS & $\mathrm{Na}^{+}$ & $\mathrm{K}^{+}$ & $\mathrm{Mg}^{2+}$ & $\mathrm{Ca}^{2+}$ & $\mathrm{Cl}^{-}$ & $\mathrm{SO}_{4}{ }^{2-}$ & $\mathrm{HCO}_{3}{ }^{-}$ & $\mathrm{CO}_{3}{ }^{2-}$ \\
\hline $\mathrm{pH}$ & 1.000 & 0.623 & $0.687^{*}$ & -0.064 & -0.376 & -0.441 & 0.119 & 0.277 & $0.758^{*}$ & $0.808^{* *}$ \\
\hline TDS & & 1.000 & $0.994^{* *}$ & 0.269 & 0.092 & -0.116 & 0.609 & 0.577 & 0.457 & 0.475 \\
\hline $\mathrm{Na}^{+}$ & & & 1.000 & 0.200 & 0.005 & -0.201 & 0.544 & 0.575 & 0.549 & 0.567 \\
\hline $\mathrm{K}^{+}$ & & & & 1.000 & 0.435 & 0.345 & 0.461 & 0.13 & -0.329 & -0.287 \\
\hline $\mathrm{Mg}^{2+}$ & & & & & 1.000 & $0.953^{* *}$ & $0.827^{* *}$ & -0.453 & $-0.767^{*}$ & -0.589 \\
\hline $\mathrm{Ca}^{2+}$ & & & & & & 1.000 & $0.684^{*}$ & -0.566 & $-0.846^{* *}$ & -0.666 \\
\hline $\mathrm{Cl}^{-}$ & & & & & & & 1.000 & -0.122 & -0.330 & -0.174 \\
\hline $\mathrm{SO}_{4}^{2-}$ & & & & & & & & 1.000 & 0.472 & 0.268 \\
\hline $\mathrm{HCO}_{3}^{-}$ & & & & & & & & & 1.000 & $0.945^{* *}$ \\
\hline $\mathrm{CO}_{3}^{2-}$ & & & & & & & & & & 1.000 \\
\hline
\end{tabular}

${ }^{*}$ Correlation is significant at $p=0.05$ level (two-tailed). ${ }^{* *}$ Correlation is significant at $p=0.01$ (two-tailed).

TABle 4: Coefficient scores for each principal component in the factor analysis.

\begin{tabular}{lcccc}
\hline \multirow{2}{*}{ Parameter } & \multicolumn{4}{c}{ Principal component } \\
& PC1 & PC2 & PC3 & PC4 \\
\hline $\mathrm{pH}$ & 0.923 & -0.064 & 0.183 & 0.031 \\
$\mathrm{TDS}$ & 0.558 & 0.331 & 0.750 & 0.122 \\
$\mathrm{Na}^{+}$ & 0.633 & 0.267 & 0.721 & 0.078 \\
$\mathrm{~K}^{+}$ & -0.092 & 0.266 & 0.153 & 0.945 \\
$\mathrm{Mg}^{2+}$ & -0.309 & 0.924 & -0.086 & 0.180 \\
$\mathrm{Ca}^{2+}$ & -0.392 & 0.854 & -0.256 & 0.131 \\
$\mathrm{Cl}^{-}$ & 0.139 & 0.930 & 0.263 & 0.196 \\
$\mathrm{SO}_{4}{ }^{2-}$ & 0.059 & -0.408 & 0.894 & 0.119 \\
$\mathrm{HCO}_{3}{ }^{-}$ & 0.779 & -0.515 & 0.279 & -0.180 \\
$\mathrm{CO}_{3}^{2-}$ & 0.900 & -0.314 & 0.123 & -0.159 \\
\hline
\end{tabular}

TABLE 5: Total variance explained by each principal component.

\begin{tabular}{lccc}
\hline \multirow{2}{*}{ PC } & \multicolumn{3}{c}{ Rotated and squared loadings } \\
& Total & Variance percentage (\%) & Cumulative ratio (\%) \\
\hline PC1 & 3.261 & 32.61 & 32.61 \\
PC2 & 3.236 & 32.36 & 64.97 \\
PC3 & 2.173 & 21.73 & 86.70 \\
PC4 & 1.076 & 10.76 & 97.46 \\
\hline
\end{tabular}

the population variance, respectively, and the accumulative total is $97.46 \%$.

To intuitively express the relationship between individual index parameters, the R-mode cluster analyses of Pearson correlation and between-group linkage method are employed to classify the ionic composition of coalbed-produced water in the Dafosi biogenic gas field (Figure 5). After the cluster analysis, 10 parameters were divided into four categories, and the four PCs from the initial factor analysis had the same characteristics. The cluster analysis parameters, C1, C2, C3, and $\mathrm{C} 4$, corresponded to PC1, PC2, PC3, and PC4.

According to the coefficient scores of each PC (Table 4), and with \pm 0.7 set as the boundary [8], the parameters with absolute values $>0.7$ were highlighted (as shown in Figure 6). $\mathrm{PC1}$ mainly represented the negative ions and $\mathrm{pH}$ represented by $\mathrm{HCO}_{3}{ }^{-}$. Since the hydrolysis of $\mathrm{HCO}_{3}{ }^{-}$(i.e., $\mathrm{HCO}_{3}{ }^{-}+\mathrm{H}_{2} \mathrm{O}=$ $\mathrm{H}_{2} \mathrm{CO}_{3}+\mathrm{OH}^{-}$) exceeds its ionization (i.e., $\mathrm{HCO}_{3}^{-}=\mathrm{H}^{+}+\mathrm{CO}_{3}^{2-}$ ), causing the water was weakly alkaline [40]. Meanwhile, PC2 and PC4 were positively correlated with $\mathrm{Cl}^{-}, \mathrm{Ca}^{2+}, \mathrm{Mg}^{2+}$, and $\mathrm{K}^{+}$, which may be related to the lateral flow of groundwater or recharge of fissures when water is supplied. Most soluble ions in groundwater are diluted. $\mathrm{PC} 3$ was positively correlated with TDS, $\mathrm{Na}^{+}$, and $\mathrm{SO}_{4}{ }^{2-}$, which indicates that $\mathrm{Na}^{+}$and $\mathrm{SO}_{4}{ }^{2-}$ firmly control TDS, among which $\mathrm{Na}^{+}$accounts for $>95 \%$ of the produced water in the coalbed contributes more to TDS. Under a low concentration of $\mathrm{SO}_{4}{ }^{2-}$, this is conducive to the production of secondary biogenic gas [41].

Cluster-1 ( $\mathrm{C} 1$ ) corresponded to $\mathrm{PC} 1$, which revealed the joint controlling of $\mathrm{pH}$ by $\mathrm{HCO}_{3}{ }^{-}$and $\mathrm{CO}_{3}{ }^{2-}$. Strong correlations between $\mathrm{pH}$ and $\mathrm{CO}_{3}{ }^{2-}$ and $\mathrm{pH}$ and $\mathrm{HCO}_{3}{ }^{-}, R^{2}=0.808$ and $R^{2}=0.758$, respectively (Table 3 ), were generally produced by the reduction of $\mathrm{SO}_{4}{ }^{2-}$, indicating that this process can promote water-rock interactions. Cluster-2 (C2) corresponded to PC2, in which $\mathrm{Cl}^{-}$generally increased with increasing salinity; such a trend is often used as a marker of salt in groundwater [20]. The main cations may be related to water-rock interactions. The measured distance of $\mathrm{Mg}^{2+}$ and $\mathrm{Ca}^{2+}$ was 5 (dimensionless), indicating that the two were closely related, likely due to the recharge of water occurring close to its source. Cluster-3 (C3) corresponded to PC3 (i.e., TDS, $\mathrm{Na}^{+}$, and $\mathrm{SO}_{4}{ }^{2-}$ ), which means that the TDS of coalbed-produced water may be related to the reduction of $\mathrm{SO}_{4}^{2-}$. Finally, Cluster-4 (C4) corresponds to PC4. The fracturing fluid used for CBM drainage and production in the study area is clear water with $1 \% \mathrm{KCl}$ and $0.05 \%$ bactericide. When $\mathrm{K}^{+}$enters a coalbed, it is diluted, consumed, and replaced by $\mathrm{Na}^{+}$. Therefore, $\mathrm{C} 4$ may represent the residual $\mathrm{K}^{+}$in the fracturing fluid.

$\mathrm{PC} 1$ represents the influence factor of $\mathrm{pH}$. There is more $\mathrm{HCO}_{3}{ }^{-}$, which may be further hydrolyzed to produce $\mathrm{OH}^{-}$, and result in the produced water is weakly alkaline. PC2 describes the recharge of the water source and the resultant precipitation of $\mathrm{Ca}^{2+}$ and $\mathrm{Mg}^{2+}$, which is affected by evaporation during the recharge process, and was mainly related to the DFS-133 sampling points being located in the core of 


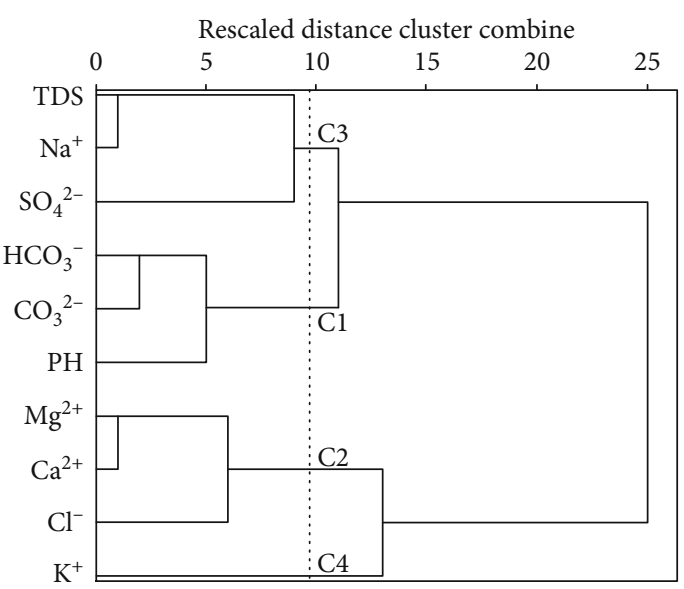

FIgURE 5: Classification results of the R-type cluster analysis.

Qijia anticline and its two wings. PC3 illustrates water-rock interactions and the reduction of $\mathrm{SO}_{4}{ }^{2-}$, which occur between groundwater and coalbeds or surrounding rocks. Low sulfate content in the samples indicates that there was a robust sulfate reduction process in the coalbed. The high sodium ion is resulted from the ion exchange and making the most outstanding contribution to TDS. These interactions will also lead to a further precipitation of $\mathrm{Ca}^{2+}$ and $\mathrm{Mg}^{2+}$. PC4 shows the influence of fracturing fluids. After a fracturing fluid penetrates underground, large amounts of $\mathrm{K}^{+}$are consumed, and $\mathrm{Na}^{+}$ions in the surrounding rocks are dissolved into the coalbed-produced water to maintain the ionic balance, and thus, $\mathrm{Na}^{+}$becomes the principal cation of coalbed-produced water under the influence of water-rock interaction.

The saturation index $[\mathrm{SI}=\lg (\mathrm{IAP} / \mathrm{Ksp})]$ is the logarithm of the ion activity product (IAP) of solution and its solubility product (Ksp) ratio [42]. The SI value represents three different states of incompatible substances, the precipitate in groundwater $(\mathrm{SI}>0)$, dissolve in groundwater $(\mathrm{SI}<0)$, and the dissolution and sedimentation balance in groundwater. They help predict the presence of reactive minerals in the aqueous water system and estimating mineral reactivity. Due to error in mineral equilibrium constants, SI range is close to $0( \pm 0.5)$, considering that $\mathrm{SI}$ is in equilibrium. Table 6 shows the calculated result of anhydrite, aragonite, calcite, dolomite, gypsum, halite, and sylvite in the study area of groundwater minerals. However, partly, samples lack aragonite, calcite, and dolomite, indicating that $\mathrm{Ca}^{2+}$ and $\mathrm{Mg}^{2+}$ are mainly from the dissolution of gypsum salts and gypsum minerals. $\mathrm{Ca}^{2+}$ and $\mathrm{Mg}^{2+}$ are precipitated secondary calcite or dolomite in an alkaline environment, resulting in a few samples in supersaturation of carbonate minerals (SI $>0$ ), such as calcite or dolomite. $\mathrm{Na}^{+}$is abundant, and all the halite are saturated. Therefore, halite is the main control factor to the chemical composition of groundwater ions. The $\mathrm{K}^{+}$in the water is low, leading to the sylvite in the unsaturated state.

4.4. Ion Source Identification. Ion sources can be determined according to the relationships between the main ion contents [43]. Most of the $\left(\mathrm{Na}^{+}+\mathrm{K}^{+}\right) / \mathrm{Cl}^{-}$in the study area plotted along the line with a slope of 1 (Figure $7(\mathrm{a})$ ), which indicates that the dissolution of sodium and potassium salts is the main source of most $\mathrm{Na}^{+}$and $\mathrm{K}^{+}$; the concentrations of $\mathrm{Na}^{+}$and $\mathrm{K}^{+}$also exceeded that of $\mathrm{Cl}^{-}$, which may be due to presence of other sources of $\mathrm{Na}^{+}$and $\mathrm{K}^{+}$, such as cation exchange. Meanwhile, $\mathrm{r}\left(\mathrm{HCO}_{3}{ }^{2-}+\mathrm{SO}_{4}{ }^{2-}\right)$ and $\mathrm{r}\left(\mathrm{Ca}^{2+}+\mathrm{Mg}^{2+}\right)$ can be used to determine the main sources of $\mathrm{Ca}^{2+}$ and $\mathrm{Mg}^{2+}$ in coalbed-produced water, where $r$ is the milligramequivalent concentration of the ions. According to Figure $7(\mathrm{~b}), \mathrm{r}\left(\mathrm{SO}_{4}{ }^{2-}+\mathrm{HCO}_{3}{ }^{2-}\right)$ and $\mathrm{r}\left(\mathrm{Ca}^{2+}+\mathrm{Mg}^{2+}\right)$ ratio do not fall on the 1:1 line, indicating that the $\mathrm{Ca}^{2+}$ and $\mathrm{Mg}^{2+}$ produced in the coalbed were not derived from the $\mathrm{CO}_{3}{ }^{2-}$ dissolution. Most of the values are below the $1: 1$ line, showing that $\mathrm{Ca}^{2+}$ and $\mathrm{Mg}^{2+}$ may come from the early dissolution of silicate minerals and gypsum salts [43].

Generally, the relationship between $\left[\left(\mathrm{Ca}^{2+}+\mathrm{Mg}^{2+}\right)\right.$ $\left.\left(\mathrm{SO}_{4}{ }^{2-}+\mathrm{HCO}_{3}^{-}\right)\right]$and $\left(\mathrm{Na}^{+}+\mathrm{K}^{+}-\mathrm{Cl}^{-}\right)$can be used to determine whether or not cation exchange has occurred [44]. According to Figure $7(\mathrm{c})$, the ratio of $\left[\left(\mathrm{Ca}^{2+}+\mathrm{Mg}^{2+}\right)-\left(\mathrm{SO}_{4}^{2-}+\mathrm{HCO}_{3}^{-}\right)\right]$ and $\left(\mathrm{Na}^{+}+\mathrm{K}^{+}-\mathrm{Cl}^{-}\right) \approx-1$, illustrating the cation exchange between $\mathrm{Na}^{+}$and $\mathrm{Ca}^{2+} / \mathrm{Mg}^{2+}$, is relatively common. Chloroalkaline index (CAI) can also be regarded as the quantified cation exchange degree [44]. In the study area, CAI-I and CAI-II were almost all negative (Figure 7(d)), and their values differed substantially, indicating that differing levels of water-rock interactions occurred during groundwater migration [45]. Furthermore, $\mathrm{Na}^{+}$or $\mathrm{K}^{+}$replaced $\mathrm{Ca}^{2+}$ and $\mathrm{Mg}^{2+}$ in the water, resulting in lower $\mathrm{Ca}^{2+}$ and $\mathrm{Mg}^{2+}$ contents in coalbed-produced waters.

4.5. Mechanism of Water-Rock Interactions. Water-rock interactions occur in the situation of long-term contact of coalbed-produced water with a rock in the ground during the water flow [46]. Sandstone is located at the top of the no. 4 coalbed (Figure 1(d)), and sodium is the dominant cation accounting for the most significant ion proportion of coalbed-produced water. The forming process of sodium in the water can be interpreted as after weathering, hydrolysis, ion exchange, and other processes, $\mathrm{Na}^{+}$was dissolved into the coalbed-produced water. At the same time, $\mathrm{Ca}^{2+}$ and $\mathrm{Mg}^{2+}$ were precipitated into rock, leading to the enrichment of $\mathrm{Na}^{+}$in the produced water and a lack of $\mathrm{Ca}^{2+}$ and $\mathrm{Mg}^{2+}$ (Figure 8). Sodium also becomes an essential factor influencing TDS concentration. The ion exchange reaction mechanisms between $\mathrm{Na}^{+}$and $\mathrm{Mg}^{2+}$ and $\mathrm{Ca}^{2+}$ in water and rock are shown in Equations (1) and (2).

$$
\begin{aligned}
& 2 \mathrm{Na}(\text { rock })+\mathrm{Ca}^{2+}(\text { water })=2 \mathrm{Na}^{+}(\text {water })+\mathrm{Ca}(\text { rock }) \\
& 2 \mathrm{Na}(\text { rock })+\mathrm{Mg}^{2+}(\text { water })=2 \mathrm{Na}^{+}(\text {water })+\mathrm{Mg}(\text { rock })
\end{aligned}
$$

When there is a certain amount of $\mathrm{HCO}_{3}{ }^{-}$in the groundwater system, the ionic exchange between $\mathrm{Ca}^{2+}$ and $\mathrm{HCO}_{3}{ }^{-}$ (Equations (3) and (4)) will replace $\mathrm{Na}^{+}$(Equation (5)) in rocks, thus reducing the content of $\mathrm{Ca}^{2+}$ in the water [47].

$$
2 \mathrm{HCO}_{3}^{-}+\mathrm{Ca}^{2+} \rightarrow \mathrm{Ca}\left(\mathrm{HCO}_{3}\right)_{2}
$$



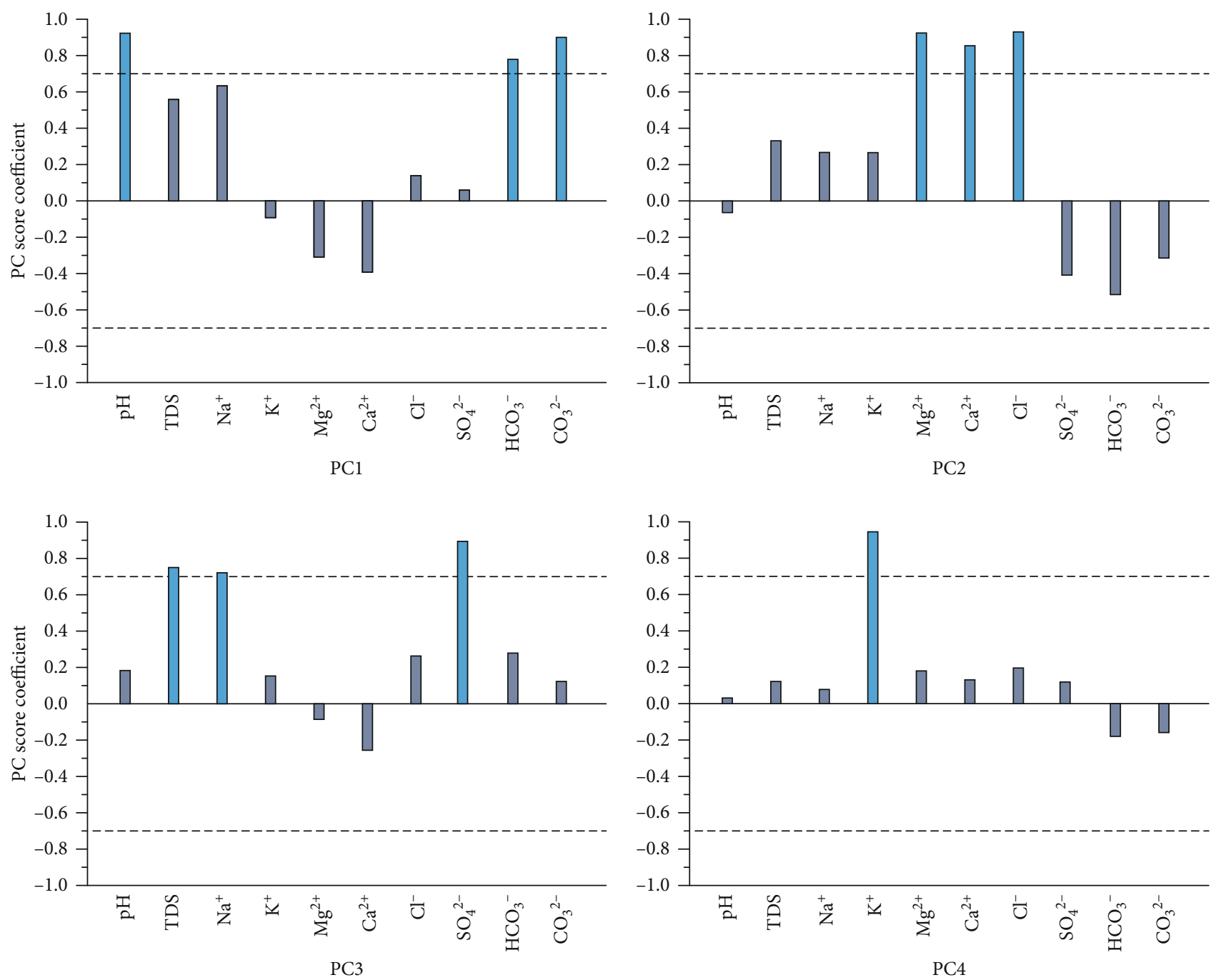

Figure 6: Coefficient scores for the PCs in the principal component analysis.

TABLE 6: Saturation indices (SI) of minerals in the coalbed-produced water.

\begin{tabular}{lcccccccccc}
\hline \multirow{2}{*}{ Minerals } & & \multicolumn{9}{c}{ Saturation index } \\
& DFS-05 & DFS-09 & DFS-45 & DFS-69 & DFS-128 & DFS-131 & DFS-133 & DFS-148 & DFS-M68 & Chemical formula \\
\hline Anhydrite & -1.33 & -1.26 & -0.53 & -1.29 & -1.22 & -0.87 & -0.08 & 0.40 & -2.11 & $\mathrm{CaSO}_{4}$ \\
Aragonite & $/$ & $/$ & $/$ & 3.16 & $/$ & $/$ & 2.40 & 2.63 & $/$ & $\mathrm{CaCO}_{3}$ \\
Calcite & $/$ & $/$ & $/$ & 3.3 & $/$ & $/$ & 2.54 & 2.77 & $/$ & $\mathrm{CaCO}_{3}$ \\
Dolomite & $/$ & $/$ & $/$ & 6.67 & $/$ & $/$ & 5.32 & 5.61 & $/$ & $\left.\mathrm{CaMg} \mathrm{CO}_{3}\right)_{2}$ \\
Gypsum & -1.18 & -1.19 & -0.43 & -1.19 & -1.14 & -0.79 & 0.01 & 0.48 & -1.92 & $\mathrm{CaSO}_{4} \bullet 2 \mathrm{H}_{2} \mathrm{O}$ \\
Halite & -0.37 & 0.18 & -0.02 & -0.01 & 0.13 & 0.07 & -0.02 & -0.01 & -0.70 & $\mathrm{NaCl}$ \\
Sylvite & -2.52 & -2.13 & -2.22 & -2.65 & -2.14 & 1.67 & -2.40 & -2.10 & -2.80 & $\mathrm{KCl}$ \\
\hline
\end{tabular}

Note: " " indicates that the mineral does not occur in the water.

$$
\begin{gathered}
\mathrm{Ca}\left(\mathrm{HCO}_{3}\right)_{2} \rightarrow \mathrm{CaCO}_{3}+\mathrm{H}_{2} \mathrm{O}+\mathrm{CO}_{2} \\
\mathrm{Ca}^{2+}(\text { water })+2 \mathrm{HCO}_{3}^{-}+2 \mathrm{Na}(\text { rock }) \rightarrow 2 \mathrm{Na}^{+}(\text {water }) \\
+2 \mathrm{HCO}_{3}^{-}+\mathrm{Ca}(\text { rock })
\end{gathered}
$$

Ion contents are also important indicators of the sedimentary environment [48]. The high content of $\mathrm{Na}^{+}$and low ranges of $\mathrm{Ca}^{2+}$ and $\mathrm{Mg}^{2+}$ of the water in the central and western parts of the study area show that the underground coalbed was in a closed groundwater environment. Because the floor of the no. 4 coalbed developed a stable, waterresistant layer, and the apex was a vulnerable aquifer. The sampling points (DFS-45, DFS-05, DFS-131, and DFSM68) in the central and eastern parts of the Dafosi biogenic 


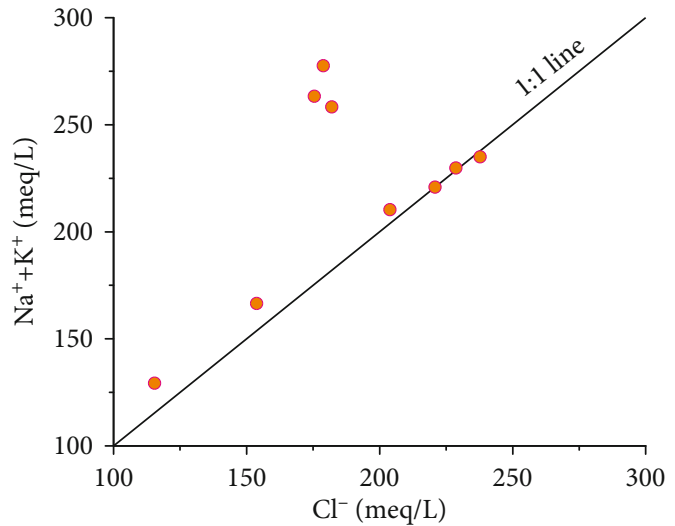

(a)

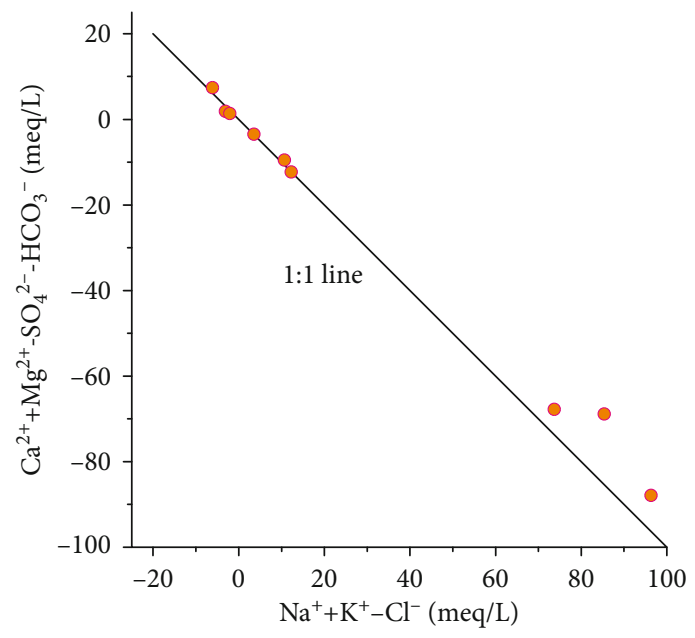

(c)

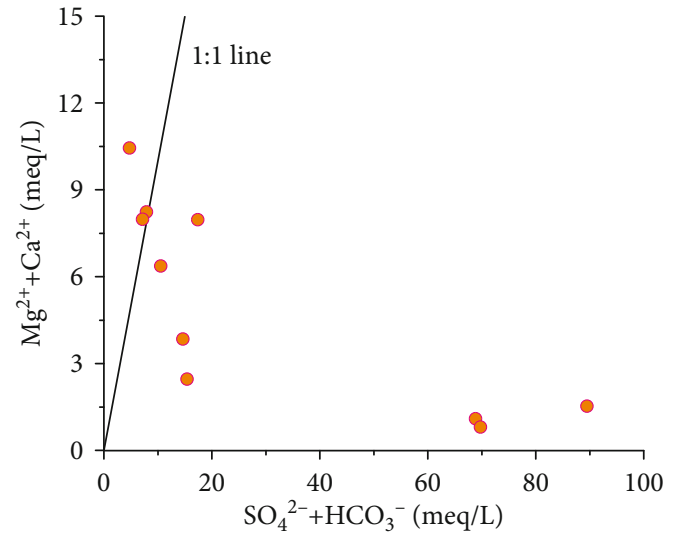

(b)

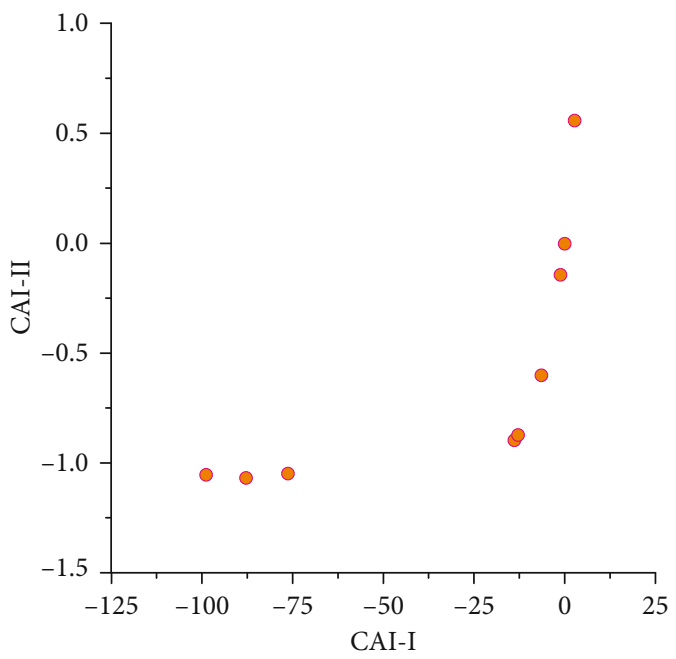

(d)

FIGURE 7: Relationship between hydrochemical compositions: (a) molar ratio of TDS vs. $\left(\mathrm{Na}^{+}+\mathrm{K}^{+}\right)$; (b) molar ratio of $\left(\mathrm{SO}_{4}{ }^{2-}+\mathrm{HCO}_{3}{ }^{-}\right)$vs. $\left(\mathrm{Ca}^{2+}+\mathrm{Mg}^{2+}-\mathrm{SO}_{4}{ }^{2-}-\mathrm{HCO}_{3}{ }^{-}\right)$; (c) $\left(\mathrm{Na}^{+}+\mathrm{K}^{+}-\mathrm{Cl}^{-}\right)$vs. $\left(\mathrm{Mg}^{2+}+\mathrm{Ca}^{2+}\right)$; (d) chloro-alkaline indices $(\mathrm{CAI}), \mathrm{CAI}-\mathrm{I}=\left[\mathrm{Cl}^{-}-\left(\mathrm{Na}^{+}+\mathrm{K}^{+}\right)\right] / \mathrm{Cl}^{-}, \mathrm{CAI}-$ $\mathrm{II}=\left[\mathrm{Cl}^{-}-\left(\mathrm{Na}^{+}+\mathrm{K}^{+}\right)\right] /\left(\mathrm{SO}_{4}{ }^{2-}+\mathrm{HCO}_{3}{ }^{-}+\mathrm{CO}_{3}{ }^{2-}\right)$. The ionic unit is meq/L.

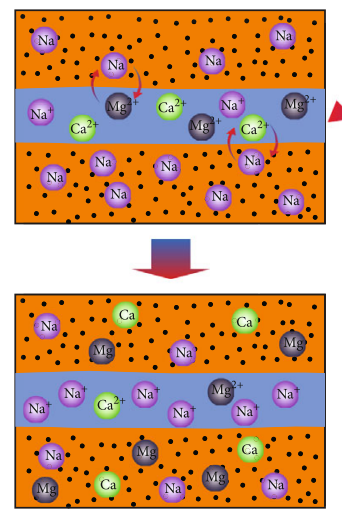

Ion exchange

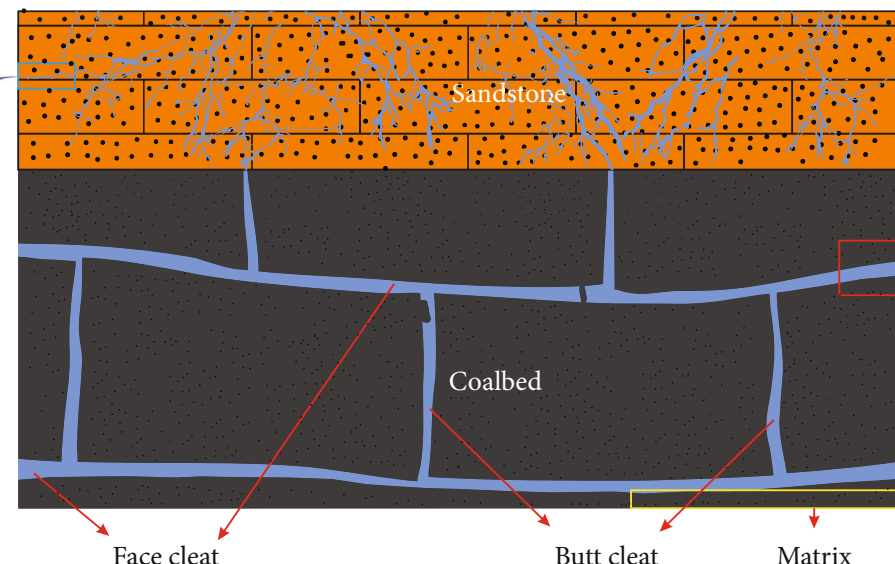

FIGURE 8: Schematic diagram of water-rock interaction.

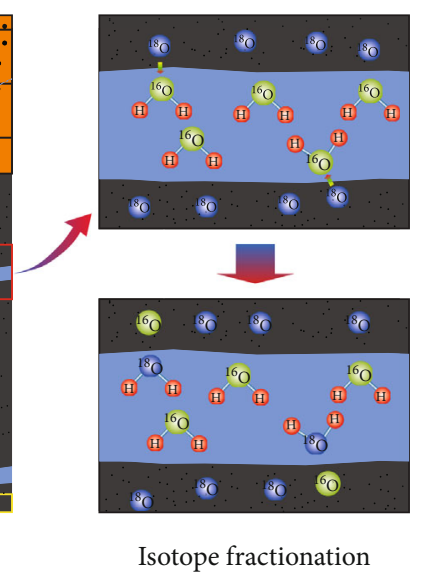

Isotope fractionation gas field also had lower $\mathrm{Na}^{+}$concentrations which means that these areas were not entirely closed. There may be faults in the core of the Qijia anticline that allow atmospheric (mete- oric) water to flow into coalbeds and migrate to both wings [27]. The TDS of the coalbed-produced water samples in the study area was generally high. Simultaneously, the 


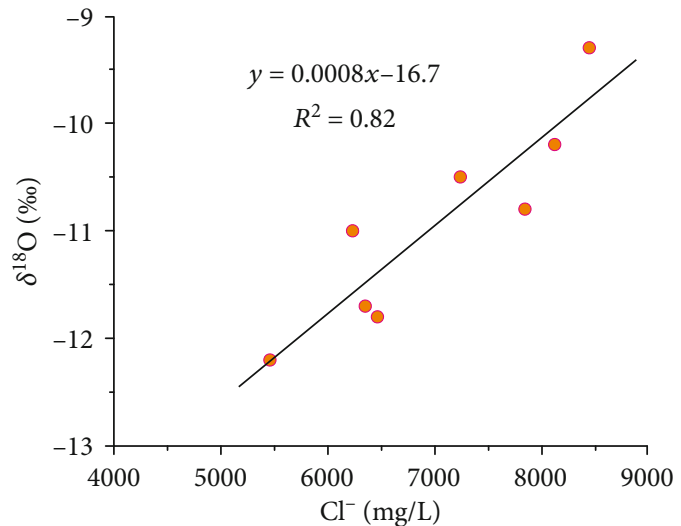

Figure 9: Chloride ion concentration and oxygen isotope composition.

coalbed depth was relatively shallow and should be affected by evaporation during early water recharge, as shown in the Gibbs diagram (Figure 3).

Hydrogen and oxygen isotopic exchange can also occur between the water and the coal organic matter when groundwater flows through the coalbed [8]. The isotopic compositions of hydrogen and oxygen of coalbed-produced water in the study area were low in ${ }^{2} \mathrm{H}$ and relatively enriched in ${ }^{18} \mathrm{O}$ in most well positions, indicating that water-rock interactions have occurred between the groundwater and coalbed. As shown in Figure 9, there was a positive correlation between chlorine ion concentration and oxygen isotope composition reflecting the mixing of meteoric water and paleoformation water in the coalbed. The lightening of the ${ }^{16} \mathrm{O}$ isotopic composition of the coal is described in Figure 8 and caused by the following reaction (Equation (6)) [8].

$$
\mathrm{H}_{2}{ }^{16} \mathrm{O}+{ }^{18} \mathrm{O}(\text { coal })=\mathrm{H}_{2}{ }^{18} \mathrm{O}+{ }^{16} \mathrm{O}(\text { coal })
$$

The ${ }^{18} \mathrm{O}$ drift characteristics of the produced water may be related because the oxygen content was higher than that of hydrogen in the coalbed [27]. The produced water sample (DFS-133) is located in the core of Qijia anticline plotted on the CMWL, showing meteoric water recharge characteristics. Therefore, evaporation also tends to enrich heavy isotopes in the residual water, with light isotopes preferring to enter the gas phase. The reason is that the crust was uplifted due to the Yanshanian orogenies, and the overlying strata were weathered and eroded, resulting in structural fissures that connected the coal-bearing strata to the surface water environment, and evaporation occurs. The recharging of source waters by atmospheric precipitation was then conducive to the generation of secondary biogenic CBM [49].

\section{Conclusions}

The average $\mathrm{pH}$ of coalbed-produced water in the Dafosi biogenic gas field is weakly alkaline, at 8.1. The $\mathrm{Na}^{+}$content ranges from 2968 to $6367.6 \mathrm{mg} / \mathrm{L}$, accounting for $>96 \%$ of all cations, while the $\mathrm{Cl}^{-}$content ranges from 4096.6 to $8441.8 \mathrm{mg} / \mathrm{L}$ and accounts for $60-97 \%$ of all anions. The hydrodynamic conditions are weak, and the TDS concentration is generally high, ranging from 7601.9 to $16505.6 \mathrm{mg} / \mathrm{L}$, indicating that groundwater is affected by evaporation during recharge. The primary ions in the produced waters of the study area are $\mathrm{Na}^{+}, \mathrm{Cl}^{-}$, and $\mathrm{HCO}_{3}{ }^{-}$.

Four main factors (PC1-4) were determined by principal component analysis. PC1 mainly represented the $\mathrm{HCO}_{3}{ }^{-}$ hydrolyzed to produce $\mathrm{OH}^{-}$, and result in the produced water is weakly alkaline. At the same time, PC2 showed the effects of water recharge. The results of water-rock interactions are expressed as PC3, manifested as the increase in $\mathrm{Na}^{+}$in the produced water and the further reduction of $\mathrm{Ca}^{2+}$ and $\mathrm{Mg}^{2+}$, and PC4 denoted the influence of fracturing fluids on the coalbed-produced water.

The $\mathrm{Na}^{+}$in coalbed-produced water are mainly derived from the dissolution of sodic salts and exchange with $\mathrm{Ca}^{2+}$ and $\mathrm{Mg}^{2+}$ in coalbed or surrounding rocks mainly derived from the dissolution of gypsum salts or minerals, resulting in the enrichment of $\mathrm{Na}^{+}$and a lack of $\mathrm{Ca}^{2+}$ and $\mathrm{Mg}^{2+}$ in the produced water. Halite is the main control factor to the chemical composition of groundwater ions. The ${ }^{18} \mathrm{O} \mathrm{drift}$ and enrichment characteristics in the coalbed-produced water are due to oxygen isotope fractionation. Early evaporation is also contributed to the enrichment of TDS and ${ }^{18} \mathrm{O}$ in the water.

\section{Data Availability}

The (Tables 1-6) data used to support the findings of this study are included within the article.

\section{Conflicts of Interest}

The authors declare that they have no conflicts of interest.

\section{Authors' Contributions}

Yuan Bao and Chaoyong Wang contributed equally to this work.

\section{Acknowledgments}

We especially appreciate the assistance of Zheng Wang and Jiaqian Chen in collecting the samples. Liang Guo from the Xi'an University of Science and Technology is gratefully acknowledged for the discussion and constructive comments for improving the quality of the manuscript. This work was supported by the National Natural Science Foundation of China (grant numbers 41972183 and 41502156), the "Chunhui Plan" Cooperative Research for Ministry of Education and Key Laboratory of Coalbed Methane Resources, and Reservoir Formation Process of the Ministry of Education (China University of Mining and Technology) (No. 2020001).

\section{References}

[1] Z. Zhang and Y. Qin, "A preliminary investigation on water quality of coalbed natural gas produced water for beneficial uses: a case study in the southern Qinshui Basin, North 
China," Environmental Science and Pollution Research, vol. 25, no. 22, pp. 21589-21604, 2018.

[2] D. Ma, L. Li, X. Li et al., "Contrastive experiment of adsorption-desorption between $\mathrm{CH}_{4}$ and $\mathrm{CO}_{2}$ in Coal Seam 4 of Dafosi Coal Mine," Journal of China Coal Society, vol. 39, no. 9, pp. 1938-1944, 2014.

[3] Y. Bao, Y. Ju, Z. Yin, J. Xiong, G. Wang, and Y. Qi, "Influence of reservoir properties on the methane adsorption capacity and fractal features of coal and shale in the upper Permian coal measures of the South Sichuan coalfield, China," Energy Exploration \& Exploitation, vol. 38, no. 1, pp. 57-78, 2020.

[4] S. Y. Park and Y. Liang, "Biogenic methane production from coal: a review on recent research and development on microbially enhanced coalbed methane (MECBM)," Fuel, vol. 166, no. 15, pp. 258-267, 2016.

[5] Y. Bao, Y. Ju, H. Huang, J. Yun, and C. Guo, "Potential and constraints of biogenic methane generation from coals and mudstones from Huaibei coalfield, eastern China," Energy \& Fuels, vol. 33, no. 1, pp. 287-295, 2019.

[6] Y. Li, J. Yang, Z. Pan, S. Meng, K. Wang, and X. Niu, "Unconventional natural gas accumulations in stacked deposits: a discussion of upper Paleozoic coal-bearing strata in the east margin of the Ordos Basin, China," Acta Geologica Sinica English Edition, vol. 93, no. 1, pp. 111-129, 2019.

[7] Q. Huang, S. Liu, G. Wang, B. Wu, and Y. Zhang, "Coalbed methane reservoir stimulation using guar-based fracturing fluid: a review," Journal of Natural Gas Science and Engineering, vol. 66, pp. 107-125, 2019.

[8] C. Guo, Y. Qin, Y. Xia et al., "Geochemical characteristics of water produced from CBM wells and implications for commingling CBM production: a case study of the Bide-Santang Basin, western Guizhou, China," Journal of Petroleum Science and Engineering, vol. 159, pp. 666-678, 2017.

[9] Z. Zhang, Y. Qin, J. Bai, G. Li, X. Zhuang, and X. Wang, "Hydrogeochemistry characteristics of produced waters from CBM wells in southern Qinshui basin and implications for CBM commingled development," Journal of Natural Gas Science and Engineering, vol. 56, pp. 428-443, 2018.

[10] C. Guo, Y. Qin, C. Wu, and L. Lu, "Hydrogeological control and productivity modes of coalbed methane commingled production in multi-seam areas: A case study of the BideSantang Basin, western Guizhou, South China," Journal of Petroleum Science and Engineering, vol. 189, p. 107039, 2020.

[11] Y. Bao, C. Wei, and B. Neupane, "Generation and accumulation characteristics of mixed coalbed methane controlled by tectonic evolution in Liulin CBM field, eastern Ordos Basin, China," Journal of Natural Gas Science and Engineering, vol. 28, pp. 262-270, 2016.

[12] C. Harmon, "Isotopic variations in meteoric waters," Science, vol. 133, pp. 1702-1703, 1961.

[13] L. Chen, H. Gui, and X. Yin, "Monitoring of flow field based on stable isotope geochemical characteristics in deep groundwater," Environmental Monitoring and Assessment, vol. 179, no. 1-4, pp. 487-498, 2011.

[14] C. Hao, Y. Huang, P. He, and W. Sun, "Isotope drift characteristics in Ordovician limestone karst water caused by coal mining in northern China," Mine Water and the Environment, vol. 38, no. 3, pp. 507-516, 2019.

[15] E. Bozau, T. Licha, and W. LieBmann, "Hydrogeochemical characteristics of mine water in the Harz Mountains, Ger- many," Chemie der Erde-Geochemistry, vol. 77, no. 4, pp. 614-624, 2017.

[16] X. Li, X. Fu, Y. Ge, and X. Chang, "Research on sequence stratigraphy, hydrogeological units and commingled drainage associated with coalbed methane production: a case study in Zhuzang syncline of Guizhou province, China," Hydrogeology Journal, vol. 24, no. 8, pp. 2171-2187, 2016.

[17] X. Huang, G. Wang, X. Liang, L. Cui, L. Ma, and Q. Xu, "Hydrochemical and stable isotope $\left(\delta \mathrm{D}\right.$ and $\left.\delta^{18} \mathrm{O}\right)$ characteristics of groundwater and hydrogeochemical processes in the Ningtiaota coalfield, Northwest China," Mine Water and the Environment, vol. 37, no. 1, pp. 119-136, 2018.

[18] Q. Li, Y. Ju, W. Lu, G. Wang, B. Neupane, and Y. Sun, "Waterrock interaction and methanogenesis in formation water in the southeast Huaibei coalfield, China," Marine and Petroleum Geology, vol. 77, pp. 435-447, 2016.

[19] C. Wu, Z. Yang, Y. Qin, J. Chen, Z. Zhang, and Y. Li, "Characteristics of hydrogen and oxygen isotopes in produced water and productivity response of CBM wells in western Guizhou," Energy \& Fuels, vol. 32, no. 11, pp. 11203-11211, 2018.

[20] C. Guo, Y. Qin, D. Ma et al., "Ionic composition, geological signature and environmental impacts of coalbed methane produced water in China," Energy Sources, Part A: Recovery, Utilization, and Environmental Effects, vol. 11, pp. 1259-1273, 2021.

[21] P. Li, R. Tian, and R. Liu, "Solute geochemistry and multivariate analysis of water quality in the Guohua phosphorite mine, Guizhou province, China," Exposure and Health, vol. 11, no. 2, pp. 81-94, 2019.

[22] W. Chen, B. Pradhan, S. Li et al., "Novel hybrid integration approach of bagging-based fisher's linear discriminant function for groundwater potential analysis," Natural Resources Research, vol. 28, no. 4, pp. 1239-1258, 2019.

[23] Z. Zhang, D. Yan, X. Zhuang et al., "Hydrogeochemistry signatures of produced waters associated with coalbed methane production in the Southern Junggar Basin," Environmental Science and Pollution Research, vol. 26, no. 31, pp. 3195631980, 2019.

[24] B. Neogi, A. K. Singh, D. D. Pathak, and A. Chaturvedi, "Hydrogeochemistry of coal mine water of north Karanpura coalfields, India: implication for solute acquisition processes, dissolved fluxes and water quality assessment," Environment and Earth Science, vol. 76, no. 14, pp. 489-506, 2017.

[25] Y. Chen, S. Zhu, and S. Xiao, "Discussion on controlling factors of hydrogeochemistry and hydraulic connections of groundwater in different mining districts," Natural Hazards, vol. 99, no. 2, pp. 689-704, 2019.

[26] M. Redwan, A. A. Abdel Moneim, and M. A. Amra, "Effect of water-rock interaction processes on the hydrogeochemistry of groundwater west of Sohag area, Egypt," Arabian Journal of Geosciences, vol. 9, no. 2, pp. 111-125, 2016.

[27] Y. Bao, W. Wang, D. Ma et al., "Gas origin and constraint of $\delta^{13} \mathrm{C}\left(\mathrm{CH}_{4}\right)$ distribution in the Dafosi mine field in the southern margin of the Ordos Basin, China," Energy \& Fuels, vol. 34, no. 11, pp. 14065-14073, 2020.

[28] H. Xu, D. Z. Tang, D. M. Liu et al., "Study on coalbed methane accumulation characteristics and favorable areas in the Binchang area, southwestern Ordos Basin, China," International Journal of Coal Geology, vol. 95, pp. 1-11, 2012.

[29] B. Lin, H. Li, D. Yuan, and Z. Li, "Development and application of an efficient gas extraction model for low-rank high- 
gas coal beds," International Journal of Coal Science \& Technology, vol. 2, no. 1, pp. 76-83, 2015.

[30] G. Hou, M. Zhang, and F. Liu, Groundwater Exploration in Ordos Basin, Geo. Publ. House, 2008.

[31] Z. Li, S. Tang, X. Wang et al., "Relationship between water chemical composition and production of coalbed methane wells, Qinshui basin," Zhongguo Kuangye Daxue Xuebao(Journal of China University of Mining \& Technology), vol. 40, no. 3, pp. 424-429, 2011.

[32] J. Qian, L. Wang, L. Ma, Y. H. Lu, W. Zhao, and Y. Zhang, "Multivariate statistical analysis of water chemistry in evaluating groundwater geochemical evolution and aquifer connectivity near a large coal mine, Anhui, China," Environmental Earth Sciences, vol. 75, no. 9, pp. 747-757, 2016.

[33] B. Zhou, Y. Qin, and Z. Yang, "Ion composition of produced water from coalbed methane wells in western Guizhou, China, and associated productivity response," Fuel, vol. 265, p. 116939, 2020.

[34] R. J. Gibbs, "Mechanisms controlling world water chemistry," Science, vol. 170, no. 3962, pp. 1088-1090, 1970.

[35] S. Zheng, G. Hou, and B. Ni, "Study on hydrogen and oxygen stable isotopes of meteoric water in China," Chinese Science Bulletin, vol. 13, pp. 801-806, 1983.

[36] S. D. Golding, C. J. Boreham, and J. S. Esterle, "Stable isotope geochemistry of coal bed and shale gas and related production waters: a review," International Journal of Coal Geology, vol. 120, pp. 24-40, 2013.

[37] R. K. Steinhorst and R. E. Williams, "Discrimination of groundwater sources using cluster analysis, MANOVA, canonical analysis and discriminant analysis," Water Resources Research, vol. 21, no. 8, pp. 1149-1156, 1985.

[38] T. Helstrup, N. O. Jørgensen, and B. Banoeng-Yakubo, "Investigation of hydrochemical characteristics of groundwater from the Cretaceous-Eocene limestone aquifer in southern Ghana and southern Togo using hierarchical cluster analysis," Hydrogeology Journal, vol. 15, no. 5, pp. 977-989, 2007.

[39] J. E. Cortes, L. F. Muñoz, C. A. Gonzalez et al., "Hydrogeochemistry of the formation waters in the San Francisco field, UMV basin, Colombia - a multivariate statistical approach," Journal of Hydrology, vol. 539, pp. 113-124, 2016.

[40] H. Huang, S. Sang, Y. Miao, Z. Dong, and H. Zhang, "Trends of ionic concentration variations in water coproduced with coalbed methane in the Tiefa Basin," International Journal of Coal Geology, vol. 182, pp. 32-41, 2017.

[41] V. Voast and A. Wayne, "Geochemical signature of formation waters associated with coalbed methane," AAPG Bulletin, vol. 87, no. 4, pp. 667-676, 2003.

[42] Y. Guo, J. Wei, H. Gui, Z. Zhang, and M. Hu, "Evaluation of changes in groundwater quality caused by a water inrush event in Taoyuan coal mine, China," Environmental Earth Sciences, vol. 79, no. 24, p. 528, 2020.

[43] E. Lakshmanan, R. Kannan, and M. S. Kumar, "Major ion chemistry and identification of hydrogeochemical processes of ground water in a part of Kancheepuram district, Tamil Nadu, India," Environmental Geosciences, vol. 10, no. 4, pp. 157-166, 2003.

[44] Y. Li, S. Tang, S. Zhang, Z. Xi, and P. Wang, "Biogeochemistry and water-rock interactions of coalbed methane co-produced water in the Shizhuangnan block of the southern Qinshui basin, China," Water, vol. 12, no. 1, pp. 130-148, 2020.
[45] P. Li, H. Qian, J. Wu, Y. Zhang, and H. Zhang, "Major ion chemistry of shallow groundwater in the Dongsheng coalfield, Ordos basin, China," Mine Water and the Environment, vol. 32, no. 3, pp. 195-206, 2013.

[46] P. Liu, N. Hoth, C. Drebenstedt, Y. Sun, and Z. Xu, "Hydrogeochemical paths of multi-layer groundwater system in coal mining regions - using multivariate statistics and geochemical modeling approaches," Science of The Total Environment, vol. 601-602, pp. 1-14, 2017.

[47] K. Zhang, J. Gao, B. Jiang, J. Han, and M. Chen, "Experimental study on the mechanism of water-rock interaction in the coal mine underground reservoir," Journal of China Coal Society, vol. 44, no. 12, pp. 3760-3772, 2019.

[48] C. Song, Y. Zeng, M. Yan et al., "Sedimentary conditions of evaporites in the late Jurassic Xiali formation, Qiangtang Basin: evidence from geochemistry records," Acta Geologica Sinica - English Edition, vol. 91, no. 1, pp. 156-174, 2017.

[49] Q. Li, Y. Ju, Y. Bao, Z. Yan, X. Li, and Y. Sun, "Composition, origin, and distribution of coalbed methane in the Huaibei Coalfield, China," Energy \& Fuels, vol. 29, no. 2, pp. 546-555, 2015. 